Gut, 1980, 21, 1041-1046

\title{
Cell kinetics in the jejunal crypt epithelium in malabsorption syndrome with cow's milk protein intolerance and in coeliac disease of childhood
}

\author{
I KOSNAI, P KUITUNEN, E SAVILAHTI, J RAPOLA, AND J KÖHEGYI \\ From the Children's Hospital, University of Helsinki, Helsinki, Finland; the First Department of Paediatrics, \\ Semmelweis University, Budapest, Hungary; and the Department of Numerical Methods, Eötvös Lorand \\ University, Budapest, Hungary
}

SUMMARY Cell kinetics in the proximal jejunal epithelium were studied by the methods of Cairnie et $a .^{1}$ and Wright et al. ${ }^{2}$ Seventeen children with untreated malabsorption syndrome and cow's milk protein intolerance (CMI) and 12 of these on a cow's milk free diet were compared with 47 children with untreated coeliac disease, with 15 of these on a gluten free diet, and with 15 controls. The tctal number of cells in the crypts of the patients with CMI was 1.8 times $(P<0.001)$ and in patients with coeliac disease 2.4 times $(\mathrm{P}<0.001)$ that seen in the controls. During the elimination diet the total number of cells in the crypts returned to the level seen in the controls. The mitotic indices, both crude and corrected, were significantly higher $(P<0.001)$ in untreated patients with CMI and those with coeliac disease than in the controls. During dietary treatment the indices fell, but not quite to the level of the controls. These small differences between the two groups may be due to the difference in the causative agents or to the different ages of the patients.

Cell renewal in the healthy normal human small intestine was studied by Bertalanffy and Nagy. ${ }^{3}$ From counts of mitoses in adults these workers calculated that the whole epithelium lining the human duodenum is completely renewed in about two days. In adult coeliac disease the mitotic index in the jejunal epithelium of the small intestinal mucosa was found to be increased two-fold ${ }^{45}$ During the elimination diet the mitotic index returned to the level seen in the normal small intestinal mucosa. ${ }^{5}$

In 1973 Wright et al. ${ }^{2}$ described a new method for analysing cell kinetics in the small intestinal crypts from sections of peroral biopsy specimens. They showed that, in adult and childhood coeliac disease and in adults with gluten-sensitive enteropathy of dermatitis herpetiformis, there was a marked increase in the number of the proliferating cells per crypt as well as in the mitotic index in the 'flat' mucosa. These findings are consistent with Booth's ${ }^{6}$ suggestion that the characteristic changes in crypt morphology are a direct consequence of 'enteroblastic hyperplasia' compensating for excessive loss of surface enterocytes.

Received for publication 3 July 1980
Cow's milk has been shown to cause a malabsorption syndrome, cow's milk intolerance (CMI), which resembles coeliac disease ${ }^{7-9}$, though it is seen in younger infants and is characteristically transient. ${ }^{10-12}$ The intestinal damage in this syndrome is caused by the proteins in cow's milk. The damage is closely similar to that seen in coeliac disease with both light ${ }^{11}{ }^{13}$ and electron microscopy ${ }^{14}{ }^{15}$ and the local immunological reaction in the jejunal mucosa is likewise similar. ${ }^{16}$

We here compare the cell kinetics of the jejunal crypts in cow's milk intolerance and in coeliac disease before and during an appropriate dietary regimen.

\section{Methods}

PATIENTS

Group A (Table 1) consisted of 17 patients with the CMI (malabsorption syndrome with cow's milk intolerance) who had either subtotal or partial villous atrophy of the proximal jejunum. They were admitted to the Children's Hospital, University of Helsinki, because of gastrointestinal symptoms and growth failure. Every patient had malabsorption, 
Table 1 Number and sex of patients in study groups, their ages, duration of elimination diet, and findings in jejunal biopsy specimens

\begin{tabular}{|c|c|c|c|c|c|c|c|c|}
\hline \multirow[t]{3}{*}{ Group } & \multirow{3}{*}{$\begin{array}{l}\text { Number of } \\
\text { patients }\end{array}$} & \multirow{3}{*}{$\begin{array}{l}\text { Malel } \\
\text { female }\end{array}$} & \multirow{2}{*}{$\begin{array}{l}\text { Age }(y r) \\
\text { at time of } \\
\text { biopsy }\end{array}$} & \multirow{2}{*}{$\begin{array}{l}\text { Duration of } \\
\text { elimination } \\
(y r)\end{array}$} & \multicolumn{4}{|c|}{ Findings in jejunal biopsy specimens (median and range) } \\
\hline & & & & & \multirow{2}{*}{$\begin{array}{l}\text { Appearance in } \\
\text { dissecting } \\
\text { microscope }\end{array}$} & \multirow{2}{*}{$\begin{array}{l}\text { Villous } \\
\text { height }(\mu m)\end{array}$} & \multirow{2}{*}{$\begin{array}{l}\text { Intraepithelial } \\
\text { lymphocytes/ } \\
100 \text { cells }\end{array}$} & \multirow{2}{*}{$\begin{array}{l}\text { Surface } \\
\text { epithelial } \\
\text { cell height } \\
(\mu \mathrm{m})\end{array}$} \\
\hline & & & \multicolumn{2}{|c|}{ (mean and range) } & & & & \\
\hline Cow's milk intolerance & & & & & & $\begin{array}{l}191(10) \\
(150-200)\end{array}$ & $\begin{array}{l}61 \\
(40-94)\end{array}$ & $\begin{array}{l}24 \\
(19-34)\end{array}$ \\
\hline A Untreated & 17 & $8 / 9$ & $\begin{array}{l}0 \cdot 4 \\
(0 \cdot 2-0 \cdot 8)\end{array}$ & 一 & $\begin{array}{l}\text { High ridges } 3 \text {, low } \\
\text { ridges } 5 \text {, flat } \\
\text { mucosa } 4 \text {, not } \\
\text { studied } 5\end{array}$ & SVA (7) & & \\
\hline $\begin{array}{l}\text { B On a cow's milk-free } \\
\text { diet }\end{array}$ & 12 & $5 / 7$ & $\begin{array}{l}1 \cdot 3 \\
(0 \cdot 4-4 \cdot 3)\end{array}$ & $\begin{array}{l}0 \cdot 9 \\
(0 \cdot 1-3 \cdot 6)\end{array}$ & $\begin{array}{l}\text { Fingers } 2 \text {, leaves } 8 \text {, } \\
\text { not studied } 2\end{array}$ & $\begin{array}{l}363 \dagger \\
(295-496)\end{array}$ & $\begin{array}{l}30 \\
(22-44)\end{array}$ & $\begin{array}{l}33 \\
(30-42)\end{array}$ \\
\hline \multicolumn{9}{|l|}{ Coeliac disease } \\
\hline C Untreated & 47 & $17 / 30$ & $\begin{array}{l}7 \cdot 3 \\
(0 \cdot 7-21 \cdot 6)\end{array}$ & - & $\begin{array}{l}\text { Flat mucosa and } \\
\text { mosaic pattern } 42 \text {, } \\
\text { not studied } 5\end{array}$ & SVA* & $\begin{array}{l}71 \\
(54-123)\end{array}$ & $\begin{array}{l}23 \\
(18-29)\end{array}$ \\
\hline D On a gluten free diet & 15 & $7 / 8$ & $\begin{array}{l}5 \cdot 1 \\
(1 \cdot 4-11 \cdot 6)\end{array}$ & $\begin{array}{l}1 \cdot 5 \\
(0 \cdot 5-2 \cdot 3)\end{array}$ & $\begin{array}{l}\text { Fingers and leaves } \\
11 \text {, leaves and high } \\
\text { ridges } 3 \text {, not } \\
\text { studied } 1\end{array}$ & $\begin{array}{l}343 \\
(255-550)\end{array}$ & $\begin{array}{l}32 \\
(22-61)\end{array}$ & $\begin{array}{l}35 \\
(32-41)\end{array}$ \\
\hline E Controls & 15 & $10 / 5$ & $\begin{array}{l}4 \cdot 6 \\
(1 \cdot 0-15 \cdot 1)\end{array}$ & - & $\begin{array}{l}\text { Fingers and leaves } \\
13 \text {, leaves and high } \\
\text { ridges } 2\end{array}$ & $\begin{array}{l}415 \\
(302-496)\end{array}$ & $\begin{array}{l}23 \\
(11-34)\end{array}$ & $\begin{array}{l}36 \\
(30-42)\end{array}$ \\
\hline
\end{tabular}

*SVA : subtotal villous atrophy, villous height less than $150 \mu \mathrm{m}$; in many specimens villous height could not be measured because, of total lack of villi.

†Normal: villous height more than $300 \mu \mathrm{m}$.

verified by at least one of the following tests: faecal fat excretion (more than $4 \mathrm{~g}$ /day in a three-day sample), urinary excretion of D-xylose (less than $15 \%$ in five hours), urinary formiminoglutamic acid. These results improved on a diet free from cow's milk. Reintroduction of cow's milk resulted in vomiting, diarrhoea, and failure to gain weight.

Group B consisted of 12 patients from group A. Their jejunal biopsies were taken while they were on a diet free from cow's milk.

Group C consisted of 47 patients with coeliac disease. They all had total villous atrophy of the jejunum. When they were given a gluten free diet, the jejunal structure returned to normal.

Group D comprised 15 patients from group C. Their biopsies were studied when they were on a gluten free diet.

Group E consisted of 15 controls. They had been referred to the hospital because of failure to thrive. In none of these could any gastrointestinal disorder be demonstrated by careful clinical or laboratory investigations, including histological examination of the proximal jejunal mucosa.

PROXIMAL JEJUNAL BIOPSIES

Mucosal biopsies were obtained with a CrosbyKugler peroral capsule of paediatric size. All the biopsies were taken under fluoroscopic control between the level of the ligament of Treitz and $20 \mathrm{~cm}$ distally of it. They were taken between $10 \mathrm{am}$ and
12 am after an overnight fast, to minimise the diurnal variation of proliferative indices. ${ }^{17}$ All specimens were studied under the dissecting microscope and fixed in $10 \%$ neutral buffered, formol saline. Specimens were embedded in paraffin-wax and cut serially at $5 \mu \mathrm{m}$. They were stained with haematoxylin and eosin.

The morphology of the specimens was studied by measuring the height of the villi, the height of the surface epithelial cells, ${ }^{9}$ and the number of intraepithelial lymphocytes. ${ }^{18}$ In many specimens from untreated patients, however, measurement of villous height was not possible because of total lack of villi. The measurements showed severe damage and inflammation of the jejunal mucosa of untreated patients with CMI and with coeliac disease, the changes being less pronounced in CMI (Table 1). Ten patients with untreated CMI had partial villous atrophy (villous height $150-300 \mu \mathrm{m}$ ) and seven had subtotal villous atrophy (villous height less than $150 \mu \mathrm{m})$, while subtotal villous atrophy was seen in all specimens of untreated coeliac disease (Table 1). The measurements improved in patients on an appropriate elimination diet.

CRYPT ANALYSIS

The counting technique described by Cairnie et al. ${ }^{1}$ and Wright et al. ${ }^{2}$ was used. In the biopsies an average of 25 crypt columns (range 10-40) were selected for examination. Only complete, axially 
Table 2 Numbers of cells in crypts of patients and controls

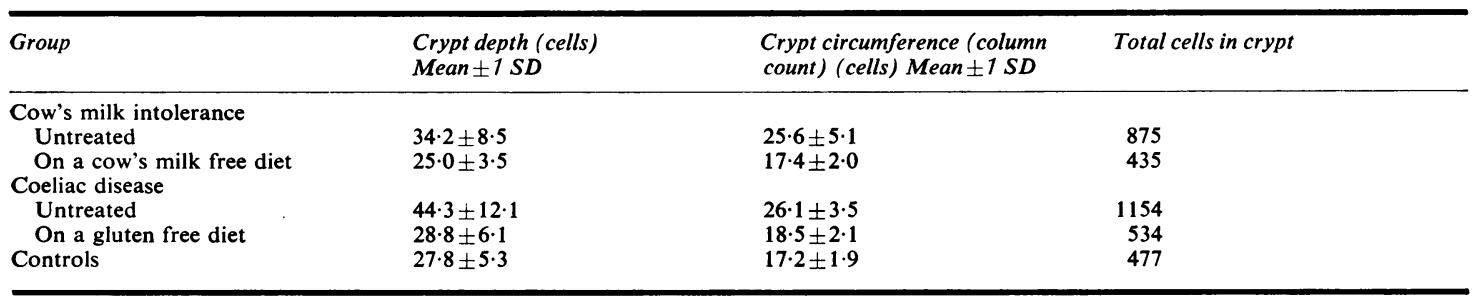

Table 3 Compartment sizes and proliferating populations of patients and controls

\begin{tabular}{|c|c|c|c|c|}
\hline \multirow[t]{2}{*}{ Group } & \multicolumn{2}{|l|}{ Column size } & \multicolumn{2}{|c|}{ Total number per crypt } \\
\hline & $\begin{array}{l}\text { Proliferative compartment } \\
(\%)\end{array}$ & $\begin{array}{l}\text { Maturation compartment } \\
(\%)\end{array}$ & Proliferating cells & Maturing cells \\
\hline \multicolumn{5}{|l|}{ Cow's milk intolerance } \\
\hline Untreated & 58 & 42 & 511 & 364 \\
\hline On a cow's milk free diet & 80 & 20 & 348 & 87 \\
\hline \multicolumn{5}{|l|}{ Coeliac disease } \\
\hline Untreated & 51 & 49 & 599 & 555 \\
\hline On a gluten free diet & 76 & 24 & 407 & 127 \\
\hline Controls & 79 & 21 & 377 & 100 \\
\hline
\end{tabular}

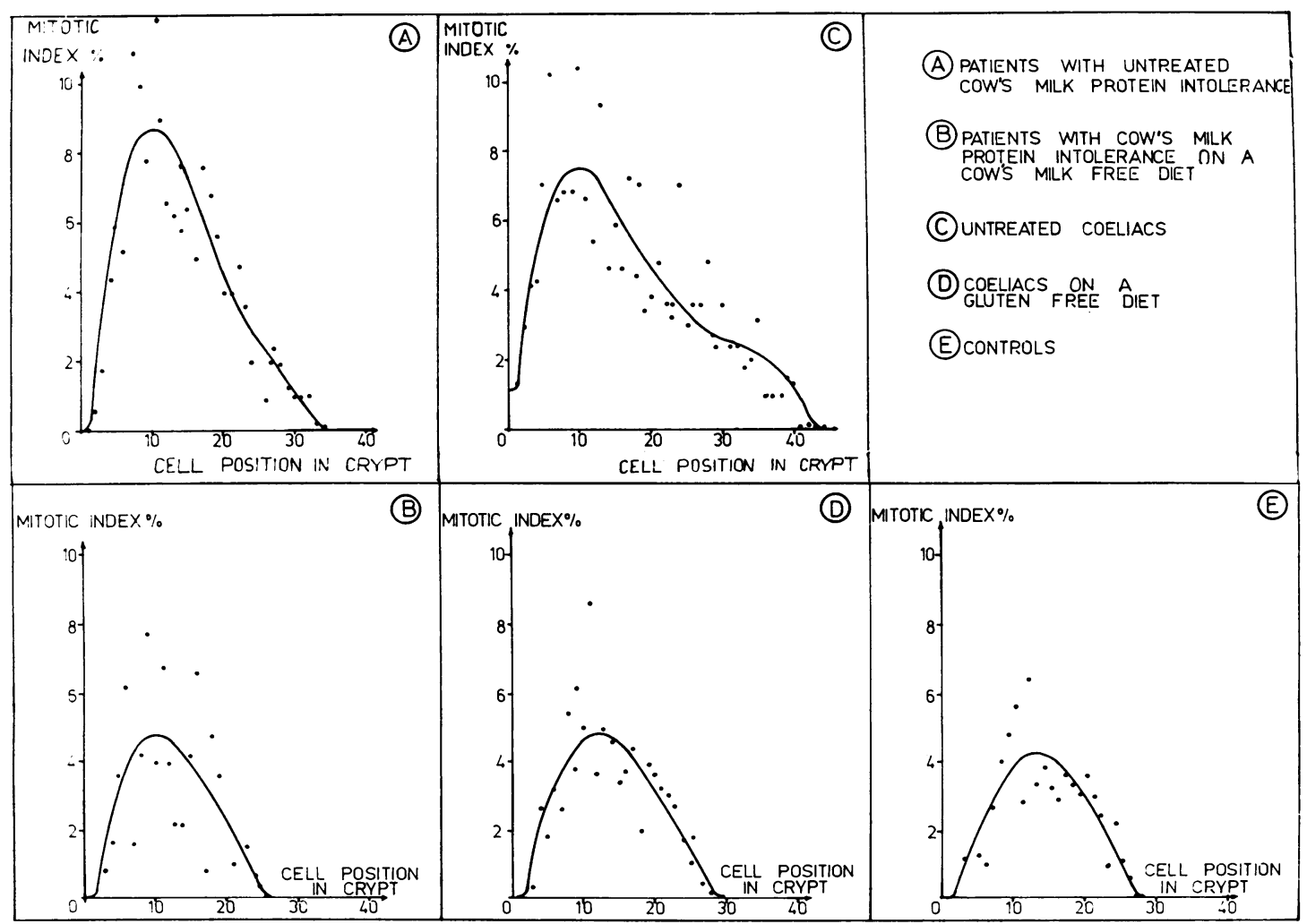

Fig. 1 The mitotic index distribution curves in the groups studied. 
sectioned crypts were accepted for analysis. The number of cells from the bottom to the crypt-villus junction (=crypt column) was counted. Only the left hand column of the crypt was counted, and a mitotic figure situated in the middle of a crypt was counted as a half. The mitotic figures in each axial crypt section were numbered, and marked in relation to their cell position. The number of cells in the circumference of each crypt (= column count) was counted from the serial sections; $50-100$ sections as complete as possible were selected for analysis. To compensate for the variation in crypt height the values for the mitotic index distribution curve were adjusted with a Fortran computer programme run on ODRA 1304 compatible with an ICL 1900 series, as described by Wright et al. ${ }^{2}$

Both the sizes of the proliferative and maturation compartments and the crude and corrected mitotic indices were calculated from the mitotic index distribution curves. ${ }^{2}$ The proliferative compartment comprises the crypt cells from the bottom of the crypt up to the level at which the mitotic index distribution curve falls to $50 \%$ of its peak value. The cells above this level form the maturation compart- ment. The crude mitotic index is the number of mitoses as a percentage of the total number of cells in the crypt. The corrected mitotic index is the percentage of mitoses in the proliferative compartment.

\section{Results}

The crypt columns were significantly deeper $(P<0.001)$ in patients with coeliac disease and in patients with CMI than in controls (Table 2). The crypts of untreated coeliac patients were also significantly deeper than those of patients with untreated CMI $(P<0.001)$. During the elimination diet the depth of the crypts in both groups returned to the values seen in the controls. The crypt circumference was significantly greater $(P<0.001)$ in untreated patients with coeliac disease and CMI than in controls. In this respect there was no difference between the patients with untreated coeliac disease and untreated CMI. When the patients were on an appropriate elimination diet the circumference of the crypt was much like that seen in the controls. Because of these increases the total number of cells

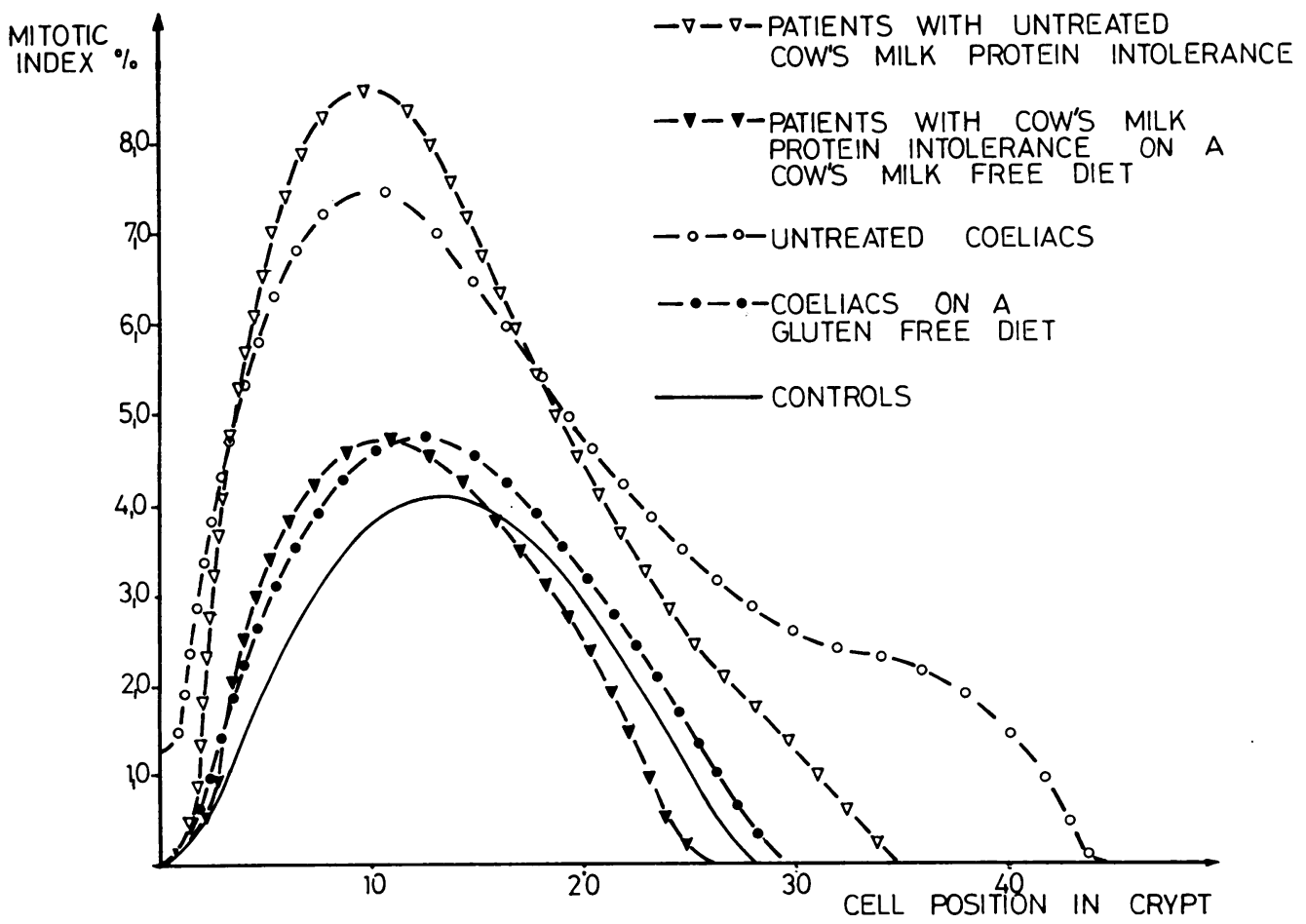

Fig. 2 Comparison of mitotic index curves in the groups studied. 
Table 4 Mitotic indices of patient and controls

\begin{tabular}{lll}
\hline Group & \multicolumn{2}{l}{ Mitotic index $(\%)$} \\
\cline { 2 - 3 } & Crude & Corrected \\
\hline Cow's milk intolerance & & \\
$\quad$ Untreated & 4.37 & 7.49 \\
$\quad$ On a cow's milk free diet & 2.87 & 3.58 \\
Coeliac disease & 3.90 & 7.52 \\
$\quad$ Untreated & 2.84 & 3.73 \\
On a gluten free diet & 2.45 & 3.10 \\
Controls & & \\
\hline
\end{tabular}

in the crypts of the patients with coeliac disease was 2.4 times the number seen in the controls, and in the patients with CMI 1.8 times that in the controls (Table 2).

The compartment sizes are summarised in Table 3. In untreated patients the maturation compartment was longer and the number of maturing cells greater. Under dietary treatment the compartment sizes returned to the values seen in the controls.

The mitotic index distribution curves for the two groups of patients are presented separately (Fig. 1) and in comparison with all groups examined (Fig. 2). The mitotic index distribution curves for the untreated patients with coeliac disease and the untreated patients with CMI are closely similar in shape, but for the patients with CMI the peak is a little higher and the curve ends at about cell position 34 . In patients with coeliac disease on a gluten free diet and in patients with CMI on a cow's milk free diet the curves are fairly similar in shape to the curve for the control group; however, they do not quite reach the level of the control group.

In untreated patients with coeliac disease and CMI both the crude and corrected mitotic indices were significantly higher $(\mathrm{P}<0.001)$ than in the controls (Table 4). During dietary treatment they fell, but not quite to the level of the controls. In patients with untreated CMI the crude mitotic index was significantly higher $(P<0.01)$ than in untreated coeliacs. When the corrected mitotic index was used, in contrast, no significant difference was seen between these two groups.

\section{Discussion}

In infants a clinical syndrome consisting of intolerance to cow's milk proteins and malabsorption has been documented. ${ }^{7-911-13}$ The damage to the proximal jejunal mucosa, when studied under the dissecting, light ${ }^{111319}$ and electron microscopes, is very similar to that seen in childhood coeliac disease $^{1415}$ In general the mucosal changes are milder in CMI than in coeliac disease, and this is true in the present study, too. Thus, 10 out of 17 patients with untreated CMI had only partial villous atrophy of the jejunum, while every one of the 47 patients with untreated coeliac disease had subtotal villous atrophy. Also the height of the surface epithelial cells was more reduced and the numbers of intraepithelial lymphocytes more increased in specimens from patients with active coeliac disease than in these from patients with CMI. The similarity between untreated coeliac disease and CMI extends to the local immunological response, with significant increases of IgA- and IgM-containing cells in the jejunal mucosa. ${ }^{16}$

In the present results the similarity of the mucosal changes in untreated coeliac disease and CMI is also evident from the mucosal cell kinetics. In both diseases the total number of crypt cells and the number of proliferating and maturing cells in the crypts are increased. These observations are similar to those made by Wright et al. ${ }^{5}(1973)$ in specimens from patients with coeliac disease and dermatitis herpetiformis, although in our patients the changes are less pronounced. Measurements made on specimens from untreated patients, however, reveal important differences between coeliac disease and CMI. The crypt column count is lower and the number of maturing cells are less numerous in CMI than in coeliac disease. Although the mitotic index distribution curves have a similar general shape in the two diseases, the peak is higher and the base narrower in CMI than in coeliac disease, and in untreated CMI the crude mitotic index is significantly higher than in untreated coeliac disease. Thus, the crypts are shorter, but they show more vigorous mitotic activity in untreated CMI than in coeliac disease. This suggests that enterocyte destruction is more rapid in CMI than in coeliac disease. The more vigorous mitotic response would be expected to lead to a more rapid recovery of the mucosa in $\mathrm{CMI}$, as has been observed. ${ }^{14}$ The present results confirm the earlier finding that in coeliac disease and CMI the intestinal mucosa gives a similar response to the damaging agent. The study of cell kinetics in coeliac disease ${ }^{2}$ reinforces the suggestion of Booth ${ }^{6}$ that there is increased loss of surface enterocytes and subsequent crypt-cell hyperplasia resulting in villous loss in active coeliac disease, and the present results suggest that this chain of events also takes place in the jejunal mucosa of patients with CMI. The pathogenesis of the cell destruction remains to be solved; it is thought to be immunological. ${ }^{16}$ The small quantitative difference between the two groups may be due to the difference in the agents causing the damage or to the difference in the ages of the patients. Younger patients have a better regeneration capacity than older ones, and their immune response differs, too. 


\section{References}

${ }^{1}$ Cairnie AB, Lamerton LF, Steel GG. Cell proliferation studies in the intestinal epithelium of the rat. I. Determination of the kinetic parameters. Exp Cell Res 1965; 39: 528-38.

${ }^{2}$ Wright N, Watson A, Morley A, Appleton D, Marks J. Cell kinetics in flat (avillous) mucosa of the human small intestine. Gut 1973; 14: 701-10.

${ }^{3}$ Bertalanffy FD, Nagy KP. Mitotic activity and renewal rate of the epithelial cells of human duodenum. Acta Anat 1961 ; 45: 362-70.

${ }^{4}$ Padykula HA, Strauss EW, Sadman AS, Gardner EH. A morphologic and histochemical analysis of the human jejunal epithelium in nontropical sprue. Gas troenterology 1961; 40: 735-65.

${ }^{5}$ Yardley JH, Bayless TM, Norton JH, Hendrix TR. Celiac disease: a study of the jejunal epithelium before and after a gluten free diet. $N$ Engl J Med 1962; 267: 1173-9.

${ }^{6}$ Booth CC. Enterocyte in coeliac disease. $\mathrm{Br}$ Med $\mathrm{J}$ 1970; 3: 725-31.

${ }^{7}$ Lamy M, Nezelof C, Jos J, Frézal J, Rey J. Biopsy of intestinal mucosa in children. First results of study of malabsorption syndromes. Press Med 1963; 71: 1267-70.

${ }^{8}$ Kuitunen P, Visakorpi JK, Hallman N. Histopathology of duodenal mucosa in malabsorption syndrome induced by cow's milk. Ann Paediatr 1965; 205 : 54-63.

${ }^{\circ}$ Kuitunen P. Duodeno-jejunal histology in the malabsorption syndrome in infants. Ann Paediatr Fenn 1966; 12: 101-32.
${ }^{10}$ Freier S, Kletter B, Gery I, Lebenthal E, Geifman M. Intolerance to milk protein. J Pediatr 1969; 75: 623-31.

${ }^{11}$ Kuitunen P, Visakorpi JK, Savilahti E, Pelkonen P. Malabsorption syndrome with cow's milk intolerance. malabsorption syndrome with cow's milk intolerance. A light and electron-microscopic study. Acta Paediatr Scand 1973; 62: 585-95.

${ }^{12}$ Déléze G, Nusslé $D$. L'intolerance aux protéines du lait de vache chez l'enfant. Helv Paediatr Acta 1975; 30: 135-49.

${ }^{13}$ Fontaine JL, Navarro J. Small intestinal biopsy in cow's milk protein allergy in infancy. Arch Dis Child 1975; 50: 357-62.

${ }^{14}$ Kuitunen P, Rapola J, Savilahti E, Visakorpi JK. Response of the jejunal mucosa to cow's milk in the

${ }^{15}$ Shiner M, Ballard J, Smith ME. The small intestinal mucosa in cow's milk allergy. Lancet $1975 ; 1$ : 136-40.

${ }^{16}$ Savilahti E. Immunochemical study of the malabsorption syndrome with cow's milk intolerance. Gut 1973; 14: 491-501.

${ }^{17}$ Sigdestad CP, Bauman J, Sesher SW. Diurnal fluctuations in the number of cells in mitosis and DNA synthesis in the jejunum of the mouse. Exp Cell Res 1969; 58: 159-62.

${ }^{18}$ Ferguson A, Murray D. Quantitation of intraepithelial lymphocytes in human jejunum. Gut 1971 ; 12: 988-94.

${ }^{19}$ Walker-Smith J, Harrison M, Kilby A, Phillips A, France N. Cow's milk-sensitive enteropathy. Arch Dis Child 1978; 53: 375-80.

Clinical findings and the course in 54 cases. Arch Dis Child 1975; 50: 351-6. 